
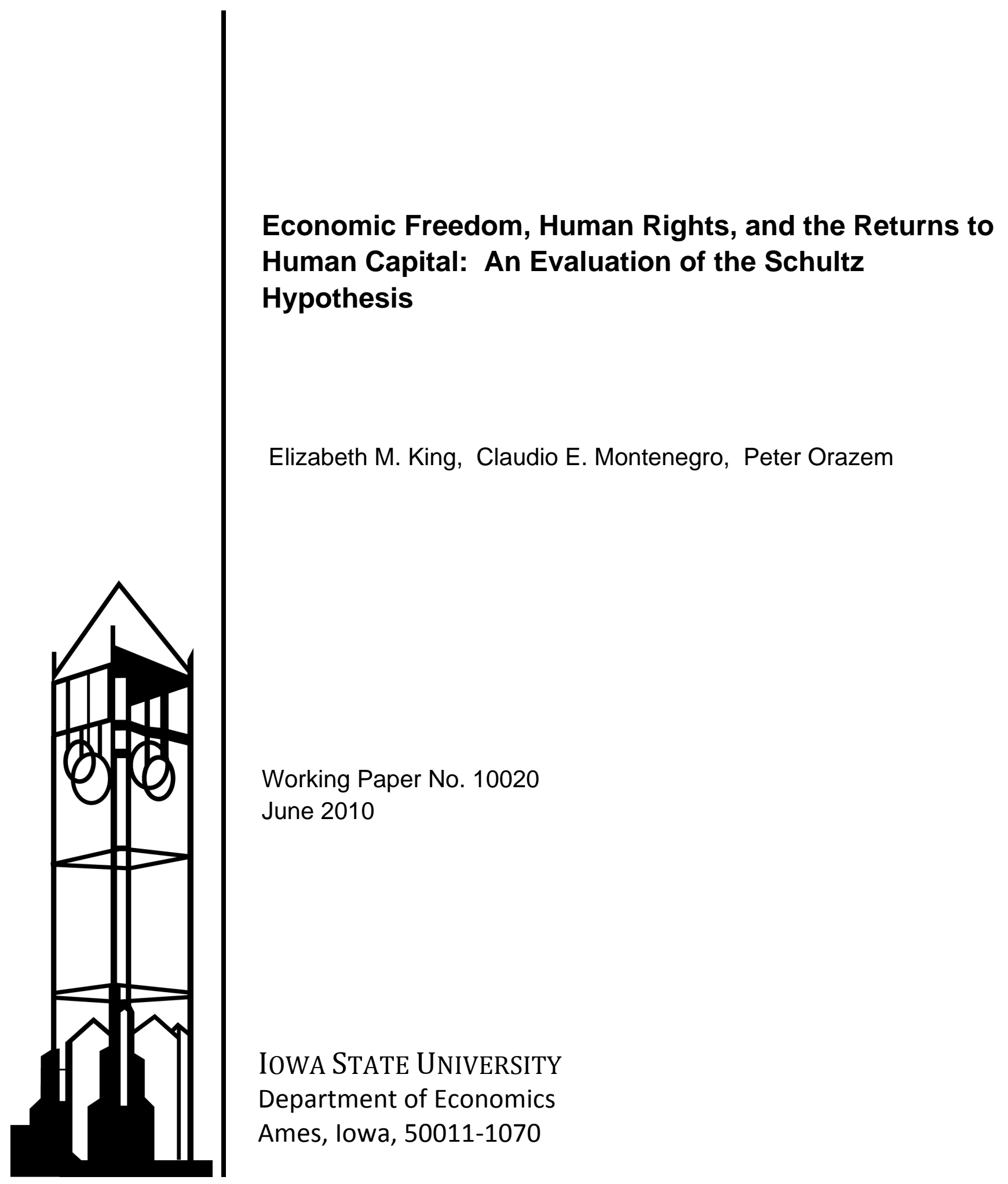

Elizabeth M. King, Claudio E. Montenegro, Peter Orazem

Working Paper No. 10020

June 2010

IOWA STATE UNIVERSITY

Department of Economics

Ames, lowa, 50011-1070 


\title{
Economic Freedom, Human Rights, and the Returns to Human Capital: An Evaluation of the Schultz Hypothesis
}

\author{
Elizabeth M. King \\ World Bank \\ Claudio E. Montenegro \\ World Bank and \\ Department of Economics, Universidad de Chile \\ Peter F. Orazem \\ Iowa State University and IZA
}

February, 2012

\begin{abstract}
The returns to human capital are said to be highest in economic environments experiencing unexpected price, productivity and technology shocks that create "disequilibria" (T.W. Schultz, 1975). In such environments, the ability of firms and individuals to adapt their resource allocations to shocks becomes most valuable. In the case of negative shocks, government policies that mitigate the impact of the shock will also limit the returns to the skills of managing risk or adapting resources to changing market forces. In the case of positive shocks, government policies may restrict access to credit, labor, or financial markets in ways that limit reallocation of resources toward newly emerging profitable sectors. This paper tests the hypothesis that the returns to skills are highest in countries that allow individuals to respond to shocks. Using estimated returns to schooling and work experience from 122 household surveys in 86 developing countries, the paper demonstrates a strong positive correlation between the returns to human capital and economic freedom, an effect that is observed throughout the wage distribution. Economic freedom benefits those workers who have attained the most schooling as well as those who have accumulated the most work experience.

JEL: J31; O15; P10

Corresponding author: Peter F. Orazem: (pfo@iastate.edu); Elizabeth M. King (eking@worldbank.org); Claudio E. Montenegro (cmontenegro@worldbank.org). Responsibility for the contents of this article is entirely ours and it should not be attributed to our affiliated institutions. We are grateful for suggestions and comments received from the referees and from atterrees at the Inter-American Develonment Bank; the Midwest Economics Meetings; the 4innesota International Economic Development Conference; and at the Festschrift for T. Paul Schultz, Center for Globat Development, Washington, DC.
\end{abstract}




\section{Introduction}

Hundreds of studies measure the private returns to schooling, most focusing on a single country or a subset of countries. Following Mincer (1974), inference on returns to schooling and work experience are derived from the regression coefficients of log earnings on years of schooling and quadratic terms in age. Due mainly to George Psacharopolous and his colleagues (Psacharopoulos 1973, Psacharopoulos 1994, Psacharopoulos and Patrinos 2004), we have compilations of estimated returns to schooling across many countries. These estimates show remarkable consistencies. Despite differences in estimation methods, specifications, and level of economic development, virtually all studies show that earnings rise with years of schooling and increase at a declining rate in age or work experience. ${ }^{1}$ In almost all data sets, the largest percentage annual wage gains are captured by the youngest workers. The wage gain from additional experience gets smaller and may even turn negative with age.

If factors flow easily across markets, the marginal returns to factors are equalized. For example, when measured properly, the marginal product of physical capital is found to be nearly equal across rich and poor countries (Lucas Jr., 1990; Caselli and Feyrer, 2007), implying that credit constraints do not retard capital investments in developing countries. But while physical capital flows easily across countries, human capital does not. Therefore, there could be substantial variation in the marginal returns to human capital, even though earnings functions display similar patterns across countries.

In fact, returns per year of schooling tend to vary within a narrow range across developed countries. Estimated private returns in the United States range narrowly around $10 \%$, despite differences in data sets and methodologies employed. Returns to schooling in other developed countries are similar to those in the United States. ${ }^{2}$ But the narrow differences could be 
explained by the fact that labor flows relatively easily across rich countries compared to labor flows between poor and rich countries. For this reason, returns to human capital are relatively unequal across developing countries, an expectation borne out by the data. Indeed, estimated returns to an additional year of schooling or to an additional year of age vary tremendously across those countries. ${ }^{3}$

The average return to schooling estimated for 86 developing countries using 122 data sets is $8 \%$, reasonably consistent with returns estimated for developed countries. However, the variation across countries is substantial (figure $1 \mathrm{~A}$ ). The $90^{\text {th }}$ percentile return is more than 3 times the $10^{\text {th }}$ percentile return. The corresponding distribution of returns to experience across the same countries shows that the $90^{\text {th }}$ percentile return to experience is over 7 times larger than the $10^{\text {th }}$ percentile return (figure $1 \mathrm{~B}$ )! Given the important role that human capital plays in economic development, it is important to understand why these differences in returns arise and why they persist across countries.

T. W. Schultz (1975) advanced an important hypothesis for why returns to human capital (education and experience) vary across markets. He argued that human capital is most valuable in the presence of unexpected price, productivity, or technology shocks that require people to reallocate time and resources. Economic or political institutions that restrict responses to those shocks, such as by limiting migration or transfers of capital, will lower returns to skill. In a steady state where there are no shocks, traditional rules of thumb are efficient. When skilled individuals are not exposed to shocks that require resource allocation decisions or when they are denied the freedom to make those decisions, they are not able to capture the economic returns from their skills, thus weakening the demand for more skill acquisition. 
A first inspection of the data supports the hypothesis that freer economic institutions raise individual returns to human capital, measured narrowly by years of schooling. We divide 86 developing countries into three groups based on their relative ranking in the Heritage Foundation's Economic Freedom Index, ${ }^{4}$ with the $25 \%$ least free economies in one group, the $25 \%$ freest in another group, and the rest in the middle group (figure 2 ). We then plot the relationship between estimated returns to schooling and real gross domestic product per capita, a measure of a country's level of economic development. The private returns to schooling in the freest economies average $9.7 \%$ per year of schooling, 3 percentage points higher than the average returns in the least free economies. ${ }^{5}$ Returns for the middle group fall between the two groups. Repeating this analysis for private returns to years of experience, average returns are highest in the freest economies $(1.6 \%)$, as compared with the middle $(1.5 \%)$ and least free (1.4\%) economies (figure 3).

T. P. Schultz (1998) found that about $70 \%$ of the income inequality in the world is due to country-specific fixed effects that would include the impacts of country-specific political and economic institutions on earnings. ${ }^{6}$ Acemoglu and Robinson (2005) argued that these institutions were formed in response to exogenous influences existing at the time of a country's founding, and that these institutions tend to persist across generations. We use measures of economic and political institutions to determine if they indeed alter returns to human capital sufficiently to explain part of the persistent cross-country income inequality. We find that, consistent with the T.W. Schultz hypothesis, human capital is significantly more valuable in countries with greater economic freedom. However, the people benefiting most from more liberal economic and political institutions are those at the upper-tail of the distribution of 
unobserved abilities, suggesting that freeing human capital to seek its highest reward comes at the expense of greater wage inequality.

\section{Government Institutions and Individual Returns}

Returns to managerial skills accrue from an individual's ability to specialize according to comparative advantage, an ability that depends not only on that individual's characteristics but also on being able to trade surplus production with others. The greater the number of potential traders, the greater the returns from specialization, but government policies can expand or retard trading opportunities by raising or lowering transaction costs. As transaction costs rise, the number of profitable trades is reduced, as are the returns to specialization for talented individuals. In the limit, institutions that raise transaction costs sufficiently will eliminate all trades and drive the returns to specialized skills to zero (Yang 2003).

There are many ways that returns to skill will increase with specialization. Rosen (1983) pointed out that returns to rare skills increase with the intensity of their use so, in the limit, the rarest skills can claim very large returns. Murphy, Schleifer, and Vishny (1991) demonstrated that if the society does not expropriate earnings excessively through taxes, the most able individuals will become entrepreneurs and will be able to capture rising returns to their ability. Their entrepreneurship also raises the economy's total productivity (Romer 1986, Romer 1990, and Lucas Jr. 2002). If the trade opportunities are removed, then the returns to the skills and the incentives to invest are diminished. Furthermore, these trade opportunities have to be incorporated broadly in the expectations of the citizenry in order to shift behavior.

"Growth in the stock of useful knowledge does not generate sustained improvement in

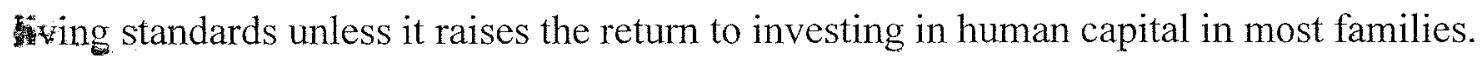


... For income growth to occur in a society, a large fraction of people must experience changes in the possible lives they imagine for themselves and their children, and these new visions of possible futures must have enough force to lead them to change the way they behave, the number of children they have, and the hopes they invest in their children." (Lucas Jr. 2002, p. 17)

Economic and political institutions are critical to forming and perpetuating these expectations. The studies by Acemoglu and his colleagues show that current political and economic institutions in developing countries have roots that go back centuries. Once installed, these institutions have a strong tendency to persist, ${ }^{7}$ even as the countries face changing economic and political circumstances. That suggests that a test of the Schultz hypothesis would be to establish whether returns to human capital are greatest in countries where economic or political institutions expose citizens to more shocks and/or provide the citizens with more freedom to adjust their time or resource allocations in response to those shocks.

Theoretical models have explicitly linked returns to individual skills to the institutions that regulate individual decision-making. Murphy, Schleifer, and Vishny (1991) show that strong property rights, ease of firm entry, and larger markets will cause the most able to become entrepreneurs, simultaneously increasing overall growth and returns to skill. Rosen (1983) demonstrates that returns to specialized applications of skill to an activity increase as transaction costs fall and the size of the market increases. Returns to skill also rise in the presence of more efficient matching institutions (Pissarides, 2000). The common feature of these models is that more efficient gains from trade among agents create increasing returns to skill. 
A compelling clue that institutions affect returns to human capital comes from the large increases in returns to education in the countries that transitioned from centrally planned economies to market systems. ${ }^{8}$ Returns to schooling more than doubled from before to after the transition (Fleisher, Sabirianova, and Wang 2005). By 2000, returns in these economies were similar to those estimated for Western Europe and North America. McMillan and Woodruff (2002) argued that the successful transition economies were those that fostered the entrepreneurial skills necessary to adapt to economic shocks. If, according to T. W. Schultz (1975), the change from a more to a less regulated economy increases the return to managerial skills because of the increased need to adapt to shocks, then there should be similar evidence of economic institutions explaining the variation in returns to schooling across all countries and not just those in transition. ${ }^{9}$

Virtually all empirical work on the role of institutions is at the country level. Moreover, there is no accepted menu of factors that should be used to measure economic institutions, and the practice has been to use institutional measures one at a time in separate growth equations. ${ }^{10}$ Because institutions may be highly correlated with one another, the coefficient attached to any given individual measure may reflect the correlation between that measure and the excluded institutions. By necessity, studies that try to control for possible endogeneity of economic institutions have to limit the number of institutions because the number of plausible instruments is limited; ${ }^{11}$ consequently, studies that aim to correct for endogeneity have to accept a higher probability of missing variables bias.

Studies of institutional effects on labor market outcomes have tended toward the opposite extreme: including an entire menu of labor market institutions as regressors. For example, Nickell and Layard (1999) employ ten measures of unionization, unemployment insurance, 
employment protection, tax distortions and other labor market policies to explain cross country variation in unemployment rates. Despite possible endogeneity bias, results using other data sets, additional institutional measures, and different time periods have generally corroborated the findings that more interventionist labor market policies exacerbate unemployment. ${ }^{12}$ Some, including Nickell and Layard (1999) and Heckman and Pages (2004) instrument for some, but not all, labor market institutions; it would be virtually impossible to instrument for all such institutions.

In this study, we employ a simple strategy of including many measures of labor market institutions at once without correcting for endogeneity. Endogeneity is much less of a concern than omitted variable bias because political and economic institutions persist over decades, such that individuals can form accurate expectations and incorporate those expectations into their human capital investment decisions. Moreover, since there is no consensus about which institutions are important to individual decision-making, letting the data speak seems less arbitrary than choosing a set menu of factors that could affect economic or political freedom.

In this study, we estimate returns to human capital (years of schooling and experience) over samples of individuals. This is consistent with the assumption that individuals make their optimal time and resource allocation decisions in response to perceived incentives.

\section{Empirical Measures of Economic and Political Institutions}

There are many ways that government regulations or policies affect an individual's expectations regarding returns to investment or the trend or variation in future economic variables. We apply different institutional measures that capture the themes in the literature; a general introduction to the measures is presented below. ${ }^{13}$

\section{A. Economic Freedom}


The closest measures of a country's economic environment come under the umbrella of economic freedom, those mechanisms that a government can use to control sources of economic shocks and those policies that restrict the scope of individual responses to those shocks. These policies have been measured as: the effect of corruption (Bardhan 2005; Murphy, Schleifer, and Vishny 1991; Murphy, Schleifer, and Vishny 1993; Schleifer and Vishny 1993); property rights (Acemoglu, Johnson, and Robinson 2001; Acemoglu, Johnson, and Robinson 2005; Acemoglu and Johnson 2005); rule of law or contract enforcement (Bardhan 2005; Acemoglu and Johnson 2005); constraints on entry (Djankov, Lopes-de-Silanes, and Schleifer 2002); privatization of state enterprises (Frydman and others 1999; Djankov and Murrell 2002); and monetary policy (Acemoglu and others 2003). However, these policies are mutually reinforcing, working more in conjunction with one another than in isolation. For that reason, it would make sense to include a larger set of policies to measure economic freedom rather than only one or two.

We use the Heritage Foundation's Index of Economic Freedom to measure institutions governing individual economic decisions. The Heritage Foundation has generated a comparable annual data series since 1994 across 163 countries on various aspects of economic freedom: the ease with which the team can open or close a business; openness to trade; taxes relative to income; the importance of government in the economy; the quality of monetary policy; openness to foreign investment; the lack of government restrictions on financial or credit markets; protection of property rights; and the lack of corruption in government. ${ }^{14}$ Although we estimate the individual effects of the subcomponents of the index, it seems clear that they are not independent. A single factor loading from a factor analysis of the dimensions of the Heritage Index explains $92 \%$ of the common variance among its subcomponents. Nevertheless, we also 
test whether the individual subcomponents have an effect on returns to skill that differs from the aggregate index.

\section{B. Globalization}

International trade and capital flows increase a country's exposure to shocks. These and other avenues of integration into the international community could affect returns to schooling. Foreign Direct Investment provides access to new technologies that can complement domestic human capital. $\mathrm{Xu}(2000)$ argues that countries can only attract foreign direct investment if they have a sufficient base of human capital. Acemoglu, Johnson, and Robinson (2005) argue that openness to trade strengthened the property rights of merchants in Europe, increasing their incentives to invest. Hanushek and Woessmann (2008) provide evidence that openness to foreign trade raises the impact of average cognitive skills on economic growth. Openness to trade may also raise returns to human capital, such as by increasing the cost of discrimination (Black and Brainerd 2004).

We use the Index of Globalization developed by Dreher (2006) for 155 countries for 1970-2006. Eleven countries were not covered in the index; we filled the missing values with the fitted values based on the index of Political Globalization and the Heritage Foundation's Trade Index. The Index of Globalization is positively correlated with Economic Freedom $(\rho=0.58)$ but there is sufficient independent variation to capture a separate effect of openness to international product and capital markets.

\section{Empowerment Rights}

Individual returns to schooling may depend also on the protection of political rights-the

right to act without fear of political retribution as opposed to the economic retribution that would be generated by the country's economic institutions. The Human Rights Dataset by Cingranelli 
and Richards (2005) includes measures of personal freedoms for 198 countries for 1981-2004. ${ }^{15}$ We use the Empowerment Rights Index which is constructed from various measures: freedom of movement within or out of the country; freedom of speech without government censorship; freedom to participate in politics; freedom of religion; and protection of worker rights. This index is positively correlated with the Economic Freedom Index, but at 0.44 , the correlation suggests that the two indexes are not identical. We examine how the subcomponents of the index perform relative to the aggregate index, although a single factor loading explains virtually all of the common variation among the subcomponents.

Individuals' political freedoms are not as clearly related to the pursuit of the highest return to human capital as are economic freedoms; yet these freedoms could contribute to a climate of creativity and innovation. Florida (2007) emphasizes that acceptance of individual differences fosters innovation and a climate of entrepreneurship.

\section{Democracy}

Presenting theory and evidence on the development of democracy, Acemoglu and Robinson (2005) view economies first developing with the elites controlling resource allocations and the masses lacking political power or economic rewards. However, economic growth leads to improved education and economic circumstances for the disenfranchised who will be tempted to take control by force. The elites then relinquish some power by extending political concessions to the middle and lower classes in order to avoid violent overthrow. Democracy is therefore associated with broad dispersion of the benefits of the economy and greater political freedom. How this affects returns to schooling is unclear. While democracy is positively correlated with rising per capita incomes, the effect is not causal. Furthermore, democracy leads to rising taxation of land and capital and so in relative terms, it is the elites who lose and the 
lower classes who gain. If the elites are the most educated, then democracy would actually lower returns to schooling.

Democracy has been associated with a general presumption that decentralized allocation of resources improves the efficiency of government services, including education, health care, sanitation, and irrigation. Evaluations find that decentralized decision-making does alter the allocation of resources (Alderman 2001; Faguet 2004; Galasso and Ravallion 2005), but it is less clear that the resources are allocated in ways that improve desired outcomes. There are numerous reasons why local control may yield poor outcomes. Bardhan (2002) and Bardhan (2005) argue that decentralized decisions are particularly prone to fail in developing countries where local officials may be subject to undue influence by prominent local families; there may be no tradition of monitoring of local officials by residents; and local officials may lack the necessary experience or skills to manage resources effectively.

We use the Freedom House Imputed Polity measure which rates countries by their democratic institutions. The scale varies from 0 to 10 with 0 being least democratic and 10 being most democratic. One concern is that we may have trouble distinguishing the effects of democratic institutions from those of economic and individual freedoms. In fact, democracies are more likely to have more economic freedoms $(\rho=0.45)$ and are more likely to protect individual political rights $(\rho=0.74) .{ }^{16}$ The variation across these countries enables us to identify the independent effects of democratic institutions from those of economic freedom or individual rights.

\section{E. Equal Rights}

Returns to education may depend on the distribution of opportunities or personal freedoms among demographic groups. Countries may have policies that provide economic or 
political freedoms generally to the populace and yet deny those freedoms to ethnic, racial or religious minority groups or to women. Unequal access to economic mobility would certainly lower returns to schooling for these disadvantaged groups, as has been shown in many studies of the effect of discrimination on earnings. The unequal access could even limit returns to schooling for members of the majority to the extent that the limitations on economic freedom lower the efficiency of resource allocation in the economy as a whole. The magnitude of this inefficiency due to the misallocation of resources increases with the size of the group that faces discriminatory access. Clark (2007) points to eighteenth-century England's broad distribution of human capital and its relatively egalitarian society as to why it, and not the more unequal China, India or Japan, was first to foster an Industrial Revolution.

Our measure of equal rights protection and access to economic opportunity focuses on the rights of women. Comprising half the population, women are a sufficiently large group to alter a country's average returns to schooling. In addition, measures of economic or political power that focus on women can be easily compared across countries. We use the percentage of women in the national legislature as our indication of equal access. Since 1997, the InterParliamentary Union (IPU) has provided a measure of the percentage of seats in the lower house parliament held by women for 188 countries. For the years for which we do not have IPU data, we use Melander's data with an adjustment made for the differences in measurement. Melander's measure (2005) includes women in the upper house starting in 1965 and covering 175 countries. There is little correlation between this measure of equal access and the other measures of institutions. For example, there is virtually zero correlation between the Heritage Foundation Index of Economic Freedom and the fraction of women in parliament. 


\section{Do Economic and Political Freedoms Raise Returns to Schooling?}

Private returns to schooling are estimated for 122 household data sets, representing 86 countries, using a standard Mincerian earnings function. ${ }^{17}$ The data sets used for the estimates are for the period 1989-2007, but about two-thirds are from 2000 or later. A list of countries included, survey dates, and estimated returns to schooling and experience can be found in King, Montenegro and Orazem (2012).

We standardize our measure of the returns to schooling by applying the same earnings specification to each data set. A common specification removes one source of spurious variation in estimated returns across countries. For each country $j$ and year $t$, we estimate equations of the form

$$
\ln \left(w_{i j t}\right)=\alpha_{j t}+r_{j t} S_{i j t}+b_{j t}^{1} A_{i j t}+b_{j t}^{2} A_{i j t}^{2}+\sum_{k=1}^{K} \beta_{k j t} X_{k i j t}+\varepsilon_{i j t}
$$

where $X_{k i j t}$ includes $K$ measures of individual attributes including marital status, gender and urban or rural residence. The estimated return per year of schooling is $r_{j t}$, the coefficient on years of schooling, $S_{i j t}$. The estimated return per year of experience is $b_{j t}=b_{j t}^{1}+2 b_{j t}^{2} \overline{A_{j t}}$, computed at the average age in the country.

Investments in human capital are the most ubiquitous investment in the world, so returns to human capital are appropriate measures of the returns to individual investments in developing countries. Households that are liquidity constrained are likely to invest first in human capital before they invest in physical capital, and only when the anticipated return to an additional investment in human capital falls to the market return on physical capital will they diversify to include physical capital. ${ }^{18}$ Even where the demand for formal schooling itself may be low, they may still invest in labor force skills through work experience, and the return to an additional year of life will reflect the investment in those skills. Figures 2 and 3 show that while there is 
considerable variation in returns across countries for schooling and work experience, almost all are positive, with returns to schooling and experience averaging $8.1 \%$ and $4.6 \%$, respectively.

There are different reasons why human capital generates returns, and we do not argue for one or another here. As shown by T.P. Schultz (1988), human capital improves individual wellbeing along many dimensions including better decisions regarding health and fertility as well as labor market performance. To the extent that these other decisions also improve labor market performance, earnings capture, at least in part, several dimensions of better decision-making that result from human capital investments.

The 122 earnings functions are estimated separately using weighted least squares. ${ }^{19}$ Because our estimated returns to experience and education are estimates with estimated variances, we use the Estimated Generalized Least Squares estimator where the appropriate weights are the inverse of the standard error of the estimated return. ${ }^{20}$ The estimated return to schooling in country $j$ in year $t, r_{j t}$, will reflect the institutional arrangements that affect the returns to skill in each country. If there are $L$ of these institutions, we can model the variation in estimated returns to schooling and experience by

$$
\begin{aligned}
& r_{j t}=\gamma_{0}+\sum_{l=1}^{L} \gamma_{l} M_{l j t}+v_{j t}^{r} \\
& b_{j t}=\delta_{0}+\sum_{l=1}^{L} \delta_{l} M_{l j t}+v_{j t}^{b}
\end{aligned}
$$

If the $l^{\text {th }}$ institution, $M_{l j t}$, affects returns to schooling or experience, then $\gamma_{l} \neq 0$ and $\delta_{l} \neq 0$. We estimate (1) and (2) in two steps. The second stage corrects for the heteroskedastic errors caused by an estimated dependent variable and for clustering by country. ${ }^{21}$ Results for the crosscountry rates of return regressions are presented in Table 1 for the entire working population and then separately for men and women and separately for urban and rural residents. Depending on the demographic sample, the regressions explain $15-32 \%$ of the cross country variation in returns 
to schooling and $3-10 \%$ of the cross-country variation in returns to experience, suggesting that institutions have a role in explaining why differences across countries in private returns to human capital can arise and persist.

\section{A. Economic Freedom}

The prediction from the Schultz hypothesis that returns to human capital increase with the presence of and ability to respond to shocks is broadly supported by the data. Higher levels of the Economic Freedom Index are strongly positively correlated with returns to schooling (table 1). At sample means, the elasticity is 0.55 . A $10 \%$ increase in the index raises returns to schooling by 0.45 percentage points. Because countries at the $75^{\text {th }}$ percentile of the Economic Freedom Index have scores that are twice that of countries at the $25^{\text {th }}$ percentile, variation in economic freedom is capable of explaining considerable variation in returns to schooling across countries. Point estimates suggest that women benefit more than men from freer institutions, although the differences are not statistically significant. More highly educated people in urban areas benefit significantly more than rural residents from freer economic institutions. In rural areas where opportunities to profit from education are more limited, returns to schooling are largely unaffected by the extent to which institutions restrict economic activity, consistent with studies that show education has less value in traditional economic settings and in rural markets.

Table 2 shows how subcomponents of the Heritage Index relate to estimated returns. In this regression, the 9 subcomponents of the Freedom Index were inserted into the regression in Table 1 in place of the overall index. Although the estimated elasticities suggest that the overall

index has the largest impact on returns to schooling, we reject the hypothesis that it is the overall index that matters and not the parts. Several elements of economic freedom that have been individually emphasized elsewhere as critical to economic growth, namely the share of private 
enterprise in the economy (freedom from government), protection of property rights, and openness to trade, significantly increase returns to schooling. Others such as freedom from corruption or financial freedom (lack of restrictions on banking) actually lower returns. These findings suggest that a country does not have to liberalize all regulations on economic decisions to enhance returns to schooling, but it also cannot rely on liberalization of a single institution to capture the full return on its schooling investments.

Returns to experience are also significantly affected by the level of economic freedom in a country, with an elasticity of 0.80 , evaluated at sample means. This effect is sufficiently large to explain substantial differences in returns to experience across countries. Point estimates suggest that the effect is nearly identical between men and women in magnitude and significance. Economic freedom has a particularly large effect on returns to experience in urban markets, significantly larger than its negligible impact in rural markets, although this difference is not statistically significant.

Three individual subcomponents of the Economic Freedom index significantly raise returns to experience. Two also raise returns to schooling: freedom from government which measures the importance of the private sector in the economy and the protection of property rights. Additionally, investment freedom which is lack of restrictions on foreign or domestic purchase or sale of stock significantly raises returns to experience. As with the returns to schooling, freedom from corruption and from banking regulations lower returns to experience. The largest elasticity is with respect to the overall index and not any one dimension of economic freedom, consistent with the earlier conclusion that returns to human capital benefit from liberal institutions across several sectors as opposed to a single magic bullet that is key to returns to skill. 


\section{B. Globalization}

Integration with global markets does not appear to affect returns to schooling, and its effect on returns to experience is negative, at least in urban markets. A plausible explanation is that foreign direct investments target sectors that employ younger workers, as appears true in at least some countries (World Bank, 2009). Consistent with that presumption, the trade freedom component of the Freedom Index increased returns to schooling but not returns to experience. As we will see later, the possible benefits from globalization become more apparent when we add additional controls.

\section{Empowerment Rights}

Returns to schooling and experience are not strongly linked to protection of individual political rights. The coefficients are insignificant for all population groups and often negative, with elasticities below 0.1 in absolute value. Of the individual components of the index whose effects are summarized in table 3 , the only element that registers positively is the right to participate in politics which has a marginally significant coefficient but a negligible elasticity. The contrast with the consistent importance of economic freedoms in enhancing returns to human capital is striking. While political freedoms are rightly emphasized as fundamental human rights, it would seem that individual returns to schooling and work experience can be maximized as long as economic freedoms are maintained, perhaps even at the cost of political freedoms.

\section{Democracy and Equal Rights}

While individual freedoms do not affect returns to human capital, the type of political system does. More democratic political institutions are correlated with higher returns to schooling across the board, and significantly so for all groups but the rural residents. The effect is quite 
large, approaching a 2 percentage point increase in returns to schooling when evaluated at sample means. The effect does not carry over to returns to experience where the coefficients are consistently small but negative. Unclear is whether the democratic institutions raise returns to human capital or if, as argued by Acemoglu and Robinson (2005), countries with better human capital endowments become more democratic.

Progress on equal rights, as indicated by the proportion of women among elected officials, does have a positive correlation with estimated returns to schooling. The elasticity is about 0.15 overall, larger in urban markets and for women and smaller for rural residents and males. The impact on returns across the population groups is not significantly different so that a $10 \%$ increase in women's political representation raises returns to schooling for all groups by about 0.1 percentage point. Any conclusion about the effect of equal access on returns to human capital more generally must be considered fragile, however, as we fail to find any systematic relationship between political access to women and returns to experience.

\section{Are returns to economic freedom robust to alternative hypotheses?}

An obvious concern regarding our findings thus far is that institutions may be correlated with other factors that affect returns to human capital. In fact, there are numerous factors that have been credited with explaining economic growth. Durlauf, Johnson, and Temple (2005) reported that 145 different variables had been shown to explain the cross-country pattern of growth in at least one analysis. Therefore, it is important to consider whether our conclusions are sensitive to the inclusion of these competing explanations. We list these competing factors along with explanations of how they could affect returns to human capital.

\section{A. The extent and pace of economic growth}


There are conflicting predictions of how the level or pace of economic development will affect the returns to schooling. In the models of Rosen (1983) and Murphy, Schleifer, and Vishny (1991), the size of the market raises the returns to entrepreneurial skills. Indeed, in the endogenous growth literature more generally, the accumulation of skills or knowledge generates increased productivity and returns to the innovator. Consequently, we would expect returns to schooling to be greatest in the most technologically advanced societies.

An alternative view to this suggests that poorer societies will underinvest in human capital, giving those who are able to afford more human capital a higher return to their investment. In the formulation of Becker and Tomes (1979) and Becker and Tomes (1986), wealthier households will invest in schooling up to the point at which the rate of return on schooling equals the rate of return on physical capital. Poorer households will cut off schooling even at levels at which returns to schooling exceed that on physical capital. That suggests that poorer economies will have higher returns to schooling.

Either view suggests that we must control for the level and pace of economic development to capture the true impact of economic institutions on the return to schooling. Furthermore, as economies develop, they can better afford liberal institutions such as democracy, redistributive taxes and transfers, rule of law, protection of property rights and from corrupt governments, and so on. Because of this correlation between the level and pace of economic development and the levels of economic or political freedom and democratic institutions, we must include controls for economic development to avoid missing variables bias.

We use the log of real gross domestic product per capita as our measure of economic development and the growth rate of real GDP per capita to reflect the pace of economic development. Finally, we include the $\log$ of the country population as a crude measure of the size 
Economic Freedom and Human Capital

of the market. These measures are available from the national accounts compiled by the United Nations Statistics Division.

\section{B. Life expectancy}

In Becker's (1994) formulation of the theory of human capital investment, individuals will continue to specialize in schooling as long as the net present value of the investment is positive. For an individual who expects to live longer it would then make sense to invest more in schooling; but since human capital investments are subject to diminishing returns, that individual will realize a lower annual return per year of schooling. To understand why, consider two otherwise identical individuals with different life expectancies who complete the same year of schooling. Both will generate the same marginal increase in human capital product after completing their last year of schooling, generating the same resulting marginal change in annual earnings. However, the present value of the returns from that year of schooling will be greater for the individual who lives longer. To optimize, the individual with greater expected longevity should increase schooling, with each additional year generating positive, but successively lower, annual increments in earnings. Life expectancy at birth is available for all countries through the World Development Indicators. $^{22,23}$

\section{Foreign aid}

There are sharp differences of opinion on the role of foreign aid in economic development. Some have argued that more foreign aid is critically necessary to foster economic development (Sachs 2005), while others have suggested that foreign aid has been ineffective (Easterly 2006, Easterly 2009). Still others emphasize the need for internally or externally generated political stabilization (Collier 2007) or a culture of capitalism (Clark 2007) before any economic development can occur. 
Economic Freedom and Human Capital

To our knowledge, the debate on foreign aid has not addressed whether and how aid benefits or hinders economic mobility within a country. Aid may be critical to the expansion of schooling opportunities and to the improvement of existing schools, in which case it should raise returns to schooling. Furthermore, to the extent that the aid is accompanied by support for setting and implementing good policies, that aid would improve economic institutions that could support higher returns. But foreign aid could also insulate the country from shocks which would lower the returns to schooling in a Schultz world. Finally, foreign aid could be misused, in which case its impact would be negligible. We use the log of real net foreign aid per capita provided by the World Development Indicators as our measure of the importance of foreign aid in the economy.

\section{The distribution of skills in the labor force}

Two major factors in changing returns to skill in developed countries have been the supply of skilled labor and the pace of technological change. Average years of schooling have risen significantly in a large majority of developing countries over the past few decades as enrollment rates, especially at the basic levels, have increased. At the same time, information technologies and other capital have tended to shift relative labor demand toward more highly skilled workers. Depending on the speed with which the relative supply of skills responds to that shift in demand, relative returns to skill can be affected. As documented by Katz and Autor (1999) and Autor, Katz, and Kearney (2008), the demand-side shifts have dominated supply responses since 1980 in the U.S. and many other developed countries, leading to rising returns to skills. How these technological shifts affect less developed economies is unclear in that production methods in low-wage environments will be less capital intensive. Nevertheless, we have incorporated a measure of skill share in the labor market as a control for the relative supply 
of skilled versus unskilled labor---the fraction of the labor force with at least 8 grades of completed schooling.

The reason for adding these controls is readily apparent when examining the correlation matrix in Table 4. Several of these control variables are highly correlated with measures of economic institutions, especially life expectancy, GDP per capita and skill share in the labor force. Therefore it is important to assess whether the estimated returns to economic institutions are really a result of these competing explanations.

Note that these control variables may themselves be subject to reverse causality. Level and growth of production per capita, ability to attract foreign aid, skill share of the workforce, and length of life might themselves reflect the level of and returns to skills in the country. We do not attempt to estimate this larger structural model; in adding these factors to the regression, we are interested in whether our conclusions hold up to competing explanations, whether or not those explanations meet a rigorous test of cause and effect.

\section{E. Results from the expanded model}

The estimated model including these control variables is included in Table 5. Their inclusion raises the share of explained variation in returns to human capital to as much as $49 \%$. As suggested by human capital investment theory, life expectancy has a consistently large negative effect on returns to schooling and returns to experience that applies to all populations. Returns to experience rises with the level of economic development, as indexed by GDP per capita, but returns to schooling are not significantly correlated with GDP per capita. Infusions of foreign aid consistently lower returns to human capital, but the effect is almost always insignificant. Returns to experience decrease as the share of skilled labor in the workforce rises, suggesting that skill and work experience may be substitutes. 
Despite the correlation between these factors and estimated returns to human capital, the conclusions from Table 1 hold up quite well. The effect of economic freedom on private returns to education and experience are as large or larger than estimated in Table 1 while remaining insignificant only in rural markets. We can still conclude that the returns to human capital are enhanced by economic institutions that allow shocks to occur, that allow individuals to act in response to those shocks with the expectation of retaining profits from their actions, and that spread those rights broadly in the population. Those benefits go to both men and women but are restricted to urban residents and to rural residents who migrate to urban markets. Differences in economic freedom explain part of the persistent cross-country variation in incomes identified by T. P. Schultz (1998).

A second conclusion from Table 1 that more democratic countries have higher returns to schooling is still supported by the evidence in Table 5. The magnitude and significance of the coefficients on the Democracy index is unchanged. Relative to absolute dictatorship, returns to schooling are nearly two percentage points higher in countries at the average level of democracy in the sample. The effect is even larger for women and is concentrated in urban markets where schooling has the greatest potential. Again, returns in rural areas are unaffected by democratic institutions.

The other institution that appeared to explain variation in returns to schooling in Table 1, the fraction of parliamentary seats held by women, loses about $50 \%$ of its marginal effect and falls in significance. It remains significant only for women. In contrast, gaining importance is the globalization index that measures the country's openness to foreign investment and information from abroad. The elasticity at sample means is about 0.6 , suggesting that returns to education are quite sensitive to globalization, even in rural markets. Returns to experience are 
largely unaffected by globalization, consistent with the presumption that it is the young who most benefit by open borders to trade in information and investment.

Two of the control variables have a systematic effect on cross-country variation in returns to human capital. First is life expectancy which greatly reduces marginal returns to both schooling and experience for all populations, consistent with Becker's theory of human capital. The second is the share of more educated workers in the population; an increase in this share is associated with a fall in returns to work experience. This implies that schooling and work experience are substitutes in production in developing countries. ${ }^{24}$

\section{Do Economic Institutions Have Similar Effects across the Wage Distribution?}

We have found consistent evidence that freer economic institutions lead to higher average returns to schooling and experience. That does not mean that all people benefit or that they benefit equally. There are good reasons to suspect that the most skilled benefit most from freer economic institutions. The models of Rosen (1983) and Murphy, Schleifer and Vishny (1991) suggest that it is the most uniquely skilled whose returns are suppressed under more restrictive economic policies, so they would gain most when those policies are relaxed. To the extent that maximizing returns to human capital requires geographic or occupational mobility, it is the highly educated who gain the most from greater mobility (T.P. Schultz 1988).

Many of the restrictive economic policies are aimed at redistributing income from the wealthy to the poor. Moderating or eliminating progressive tax rates, usury laws, minimum wages, and government services would all raise measured economic freedom, but their elimination might disadvantage the poorest segments of society, even as they benefit the wealthier groups. 
All of these reasons justify an evaluation of how economic or political freedoms affect returns to schooling at all points along the wage distribution. We address these issues by using quantile regressions to generate the cross-country distribution of estimated returns to schooling and experience at various points on the unobserved wage distribution. The quantile regressions are applied to the specification in (1) at the $0.1,0.5$, and 0.9 quantiles. Similar qualitative and quantitative results obtain when we add the potentially endogenous covariate controls as in Table 5.

It is useful to interpret the quantile regressions as moving up the distribution of unobserved skills. As we move from the lowest to highest quantile, returns to schooling fall slightly from $8.3 \%$ to $7.7 \%$ and returns to experience fall from $1.7 \%$ to $1.4 \%$. Presuming declining returns to human capital investments, the pattern is consistent with complementarities between unobserved and observed human capital: those occupying the top income quantiles must have higher stocks of experience, schooling and unobservable skills.

Armed with our estimated quantile returns for each country, we repeated the estimation strategy in (2) to explain the variation in estimated returns to schooling at each of the quantiles. We also examine evidence for changes in the effect of institutions as we go from the lower to the upper quantiles. The results are shown in Table 6 . We include a test of whether the change in coefficients between the 10 th and 90 th quantiles is statistically significant.

There is modest evidence that the benefits of economic institutions are shared unequally across the distribution of unobserved skills, but discerning a pattern is clouded by the lack of precision in the estimates at the lowest quantiles. Economic Freedom is always positively correlated with returns to schooling and experience with the largest returns going to those at the upper quantiles. The impact of Democratic government and of women in the legislature on 
Economic Freedom and Human Capital

returns to schooling is also universally positive but increase in magnitude as we move up the quantiles. Apparently, freer economic institutions and more democratic processes will increase wage inequality. However, the difference in returns between the upper and lower tails are too imprecise to say definitively that the returns are higher at the upper tail of the distribution. Furthermore, those at the lower tail are not made worse off-it is just that those at the upper tail benefit more.

On the other hand, liberalizing these government institutions does have implications for world income inequality. When a developing country raises its level of economic freedom or becomes more democratic, it raises the wages of all its citizens compared to earnings in the developed world. This would lower inequality across countries, even as it may have some modest increase in wage inequality within its boundaries.

\section{Conclusions}

There are sharp differences across developing countries in returns to years of schooling and work experience that are large enough to explain why between-country income differences are the dominant source of the world income inequality documented by T.P. Schultz (1988). T.W. Schultz (1975) argued that countries that limit the magnitude of economic shocks or that limit the degree to which individuals can react to those shocks will eliminate much of the source of the return to human capital. This paper suggests that if T.W. Schultz was correct, then differences in economic institutions across countries that limit or enhance economic freedom should be a source of the persistent differences in income levels documented by T.P. Schultz.

Using the Heritage Foundation's Economic Freedom Index as a gauge of the extent to which a country is open to market forces and allows individuals to respond to those forces, we find broad support for the Schultz hypothesis. Private returns to schooling are significantly 
Economic Freedom and Human Capital

higher in more economically free countries. The higher returns to schooling persist even when we add measures other political institutions that might affect returns and when we add controls for the level and pace of economic development, life expectancy, skill intensity and population in the country. We find similarly higher returns to work experience in more economically free countries.

The implications for freer political institutions are more mixed. More democratic countries have higher returns to schooling, but we cannot isolate the effect of individual empowerment rights on returns to human capital. Better access to political careers as indicated by the share of legislative seats held by women seems to also raise returns to schooling, but these estimated returns are more sensitive to the presence or absence of additional control variables in the regression.

There is modest evidence that more market-oriented economic institutions exacerbate within-country wage inequality. However, freer economic institutions do not lower wages at any point along the ability distribution, and so they improve the lot of all workers. In addition, because they raise wages in developing countries compared to the world average, more marketoriented policies in developing countries will tend to lower the between-country component of world income inequality.

An interesting implication of these findings for international migration is that individuals will experience the largest gains in private returns to human capital when they migrate from economically repressed to economically free countries. Should appropriate data exist for international migrants, we should find the largest gap in estimated returns to schooling or experience between expatriates and nonmovers from countries that are the least economically free. Similarly, looking at the expatriates from a given country, we should find the highest 
Economic Freedom and Human Capital

returns to human capital for the expatriates in the most economically free countries. The least market-oriented countries will experience the greatest brain-drain, or else they will have to use other means to suppress the desires of their citizens to leave. 


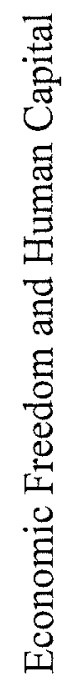

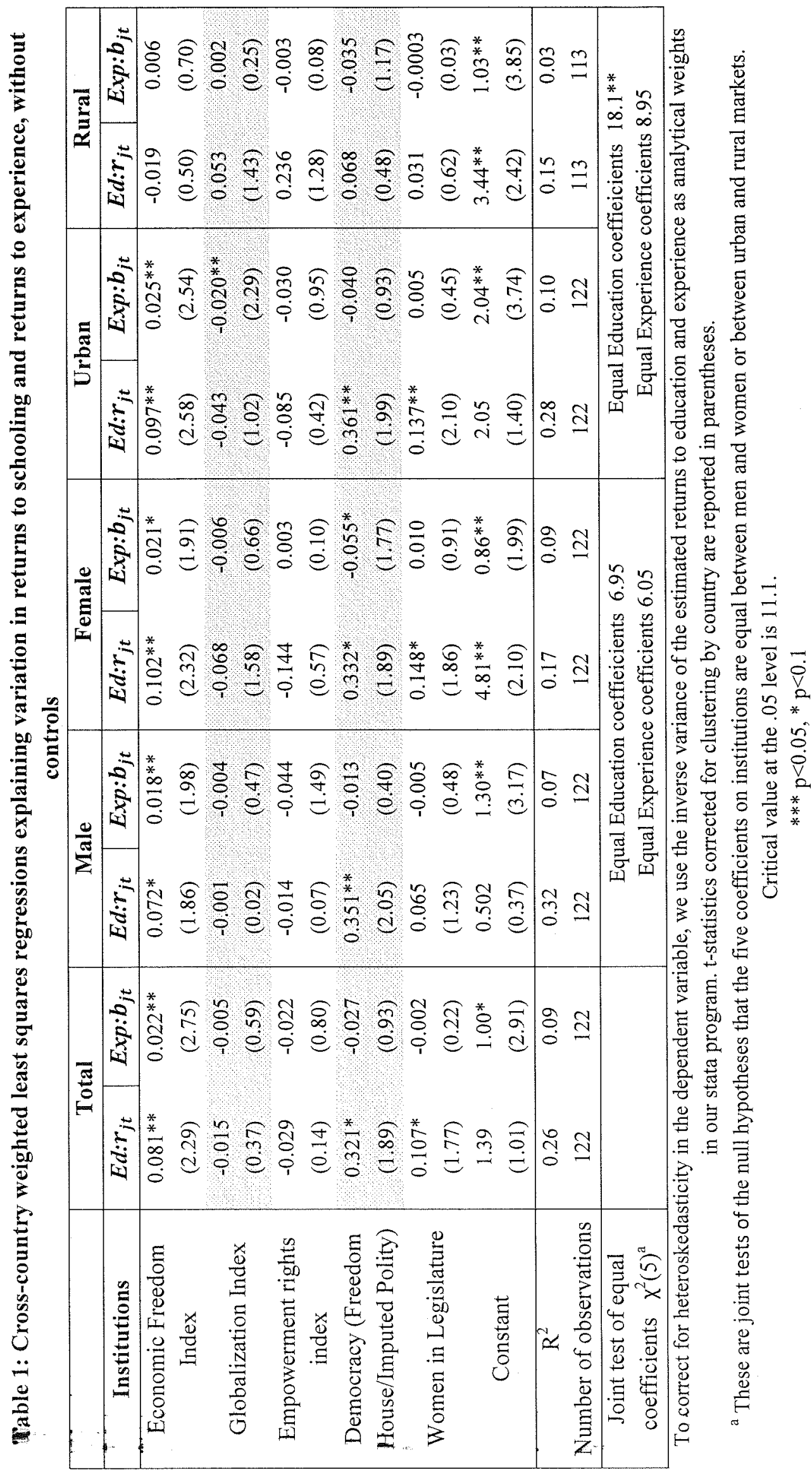




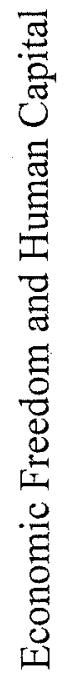

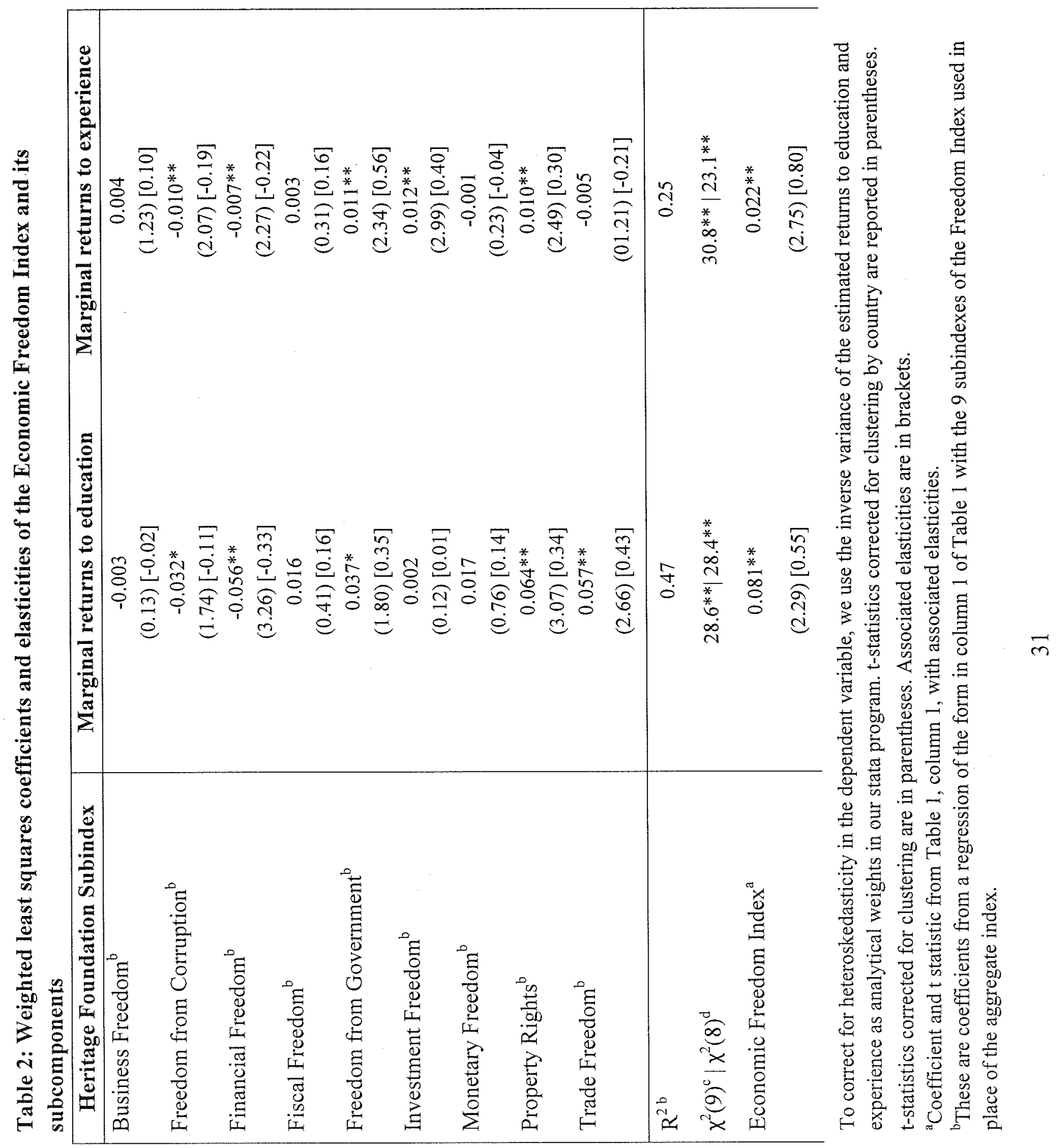




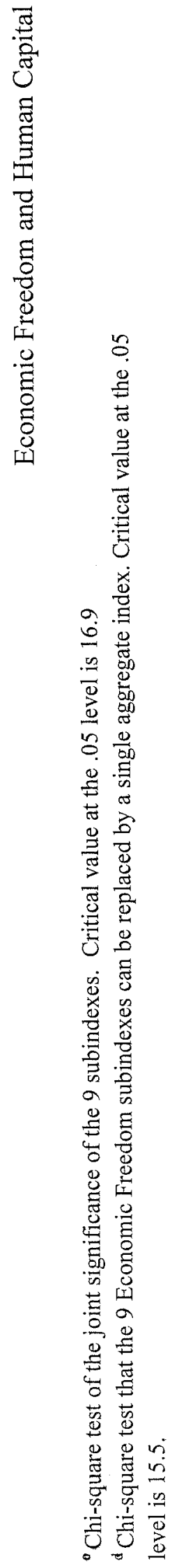




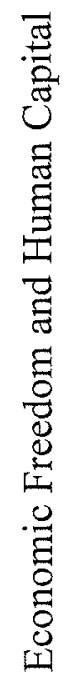

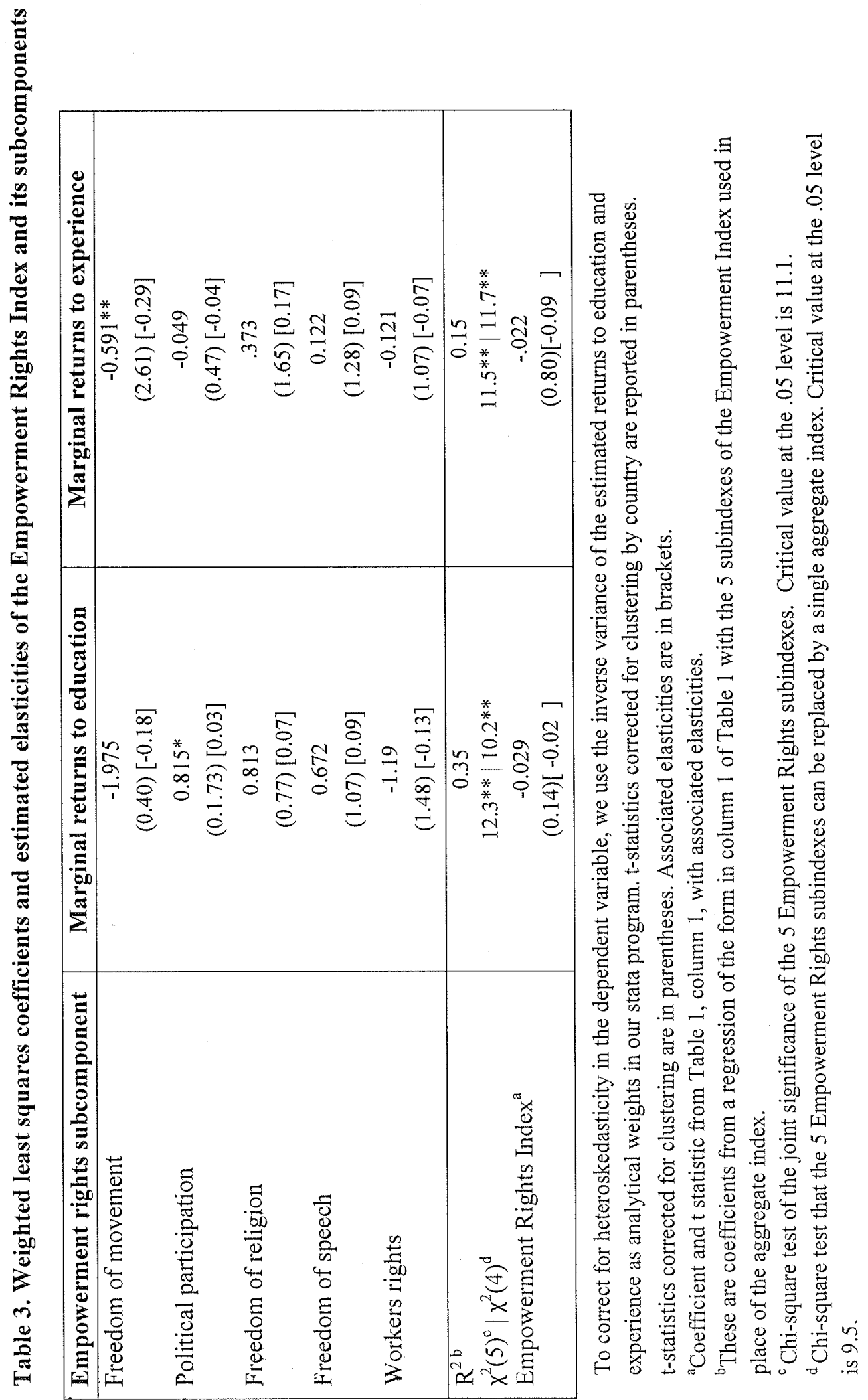

$m$ 


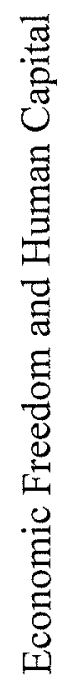

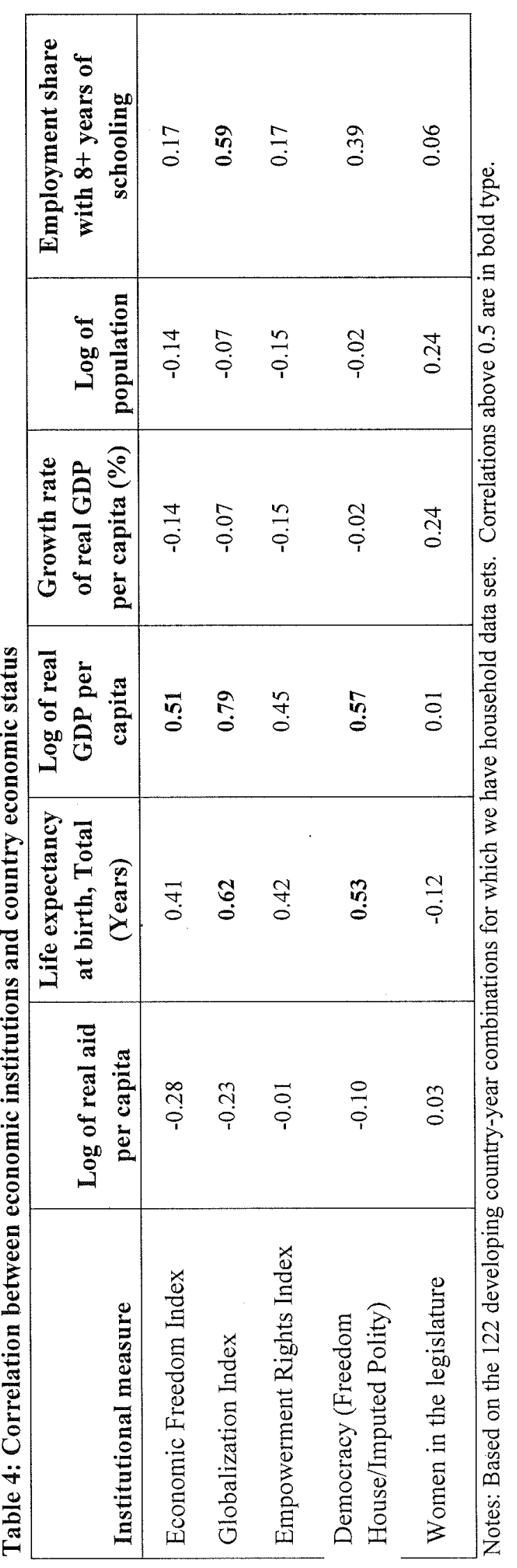




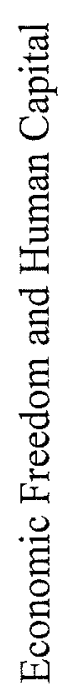

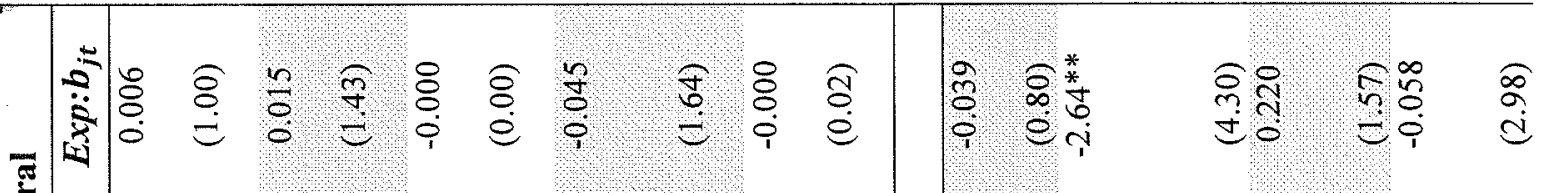

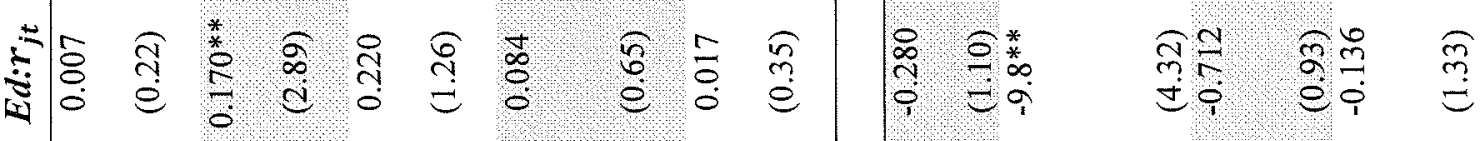

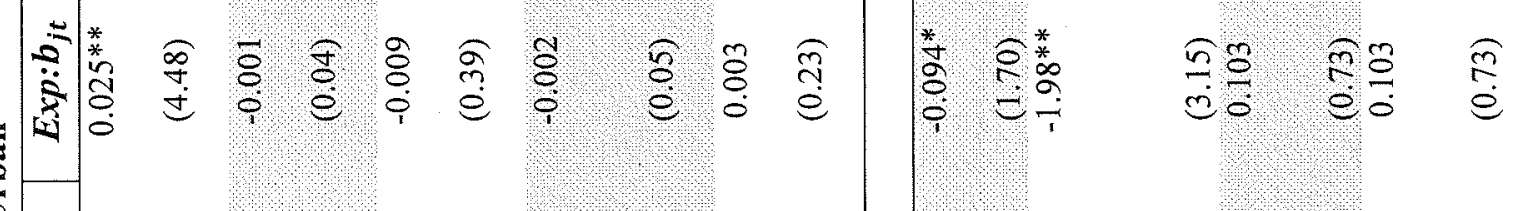

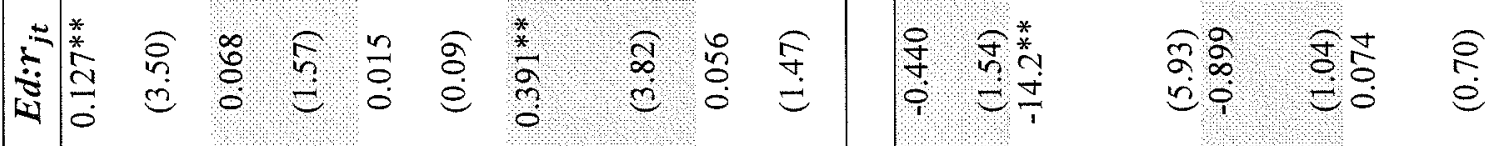

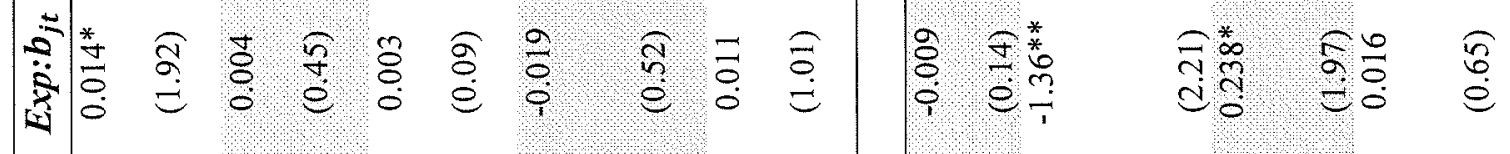

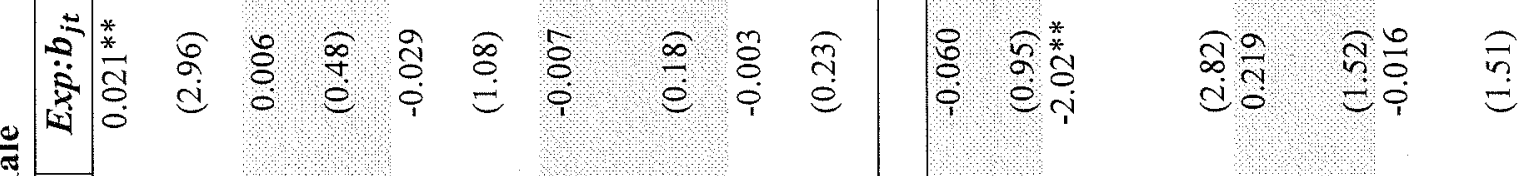

$\frac{\pi}{2}$

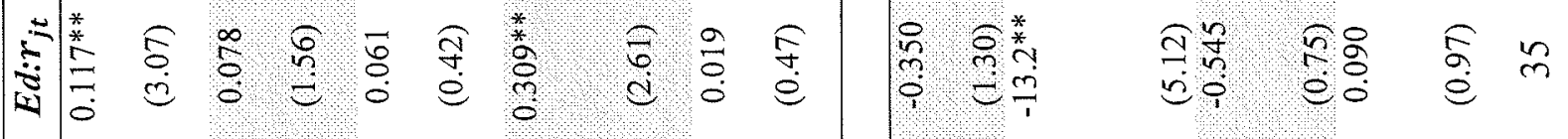

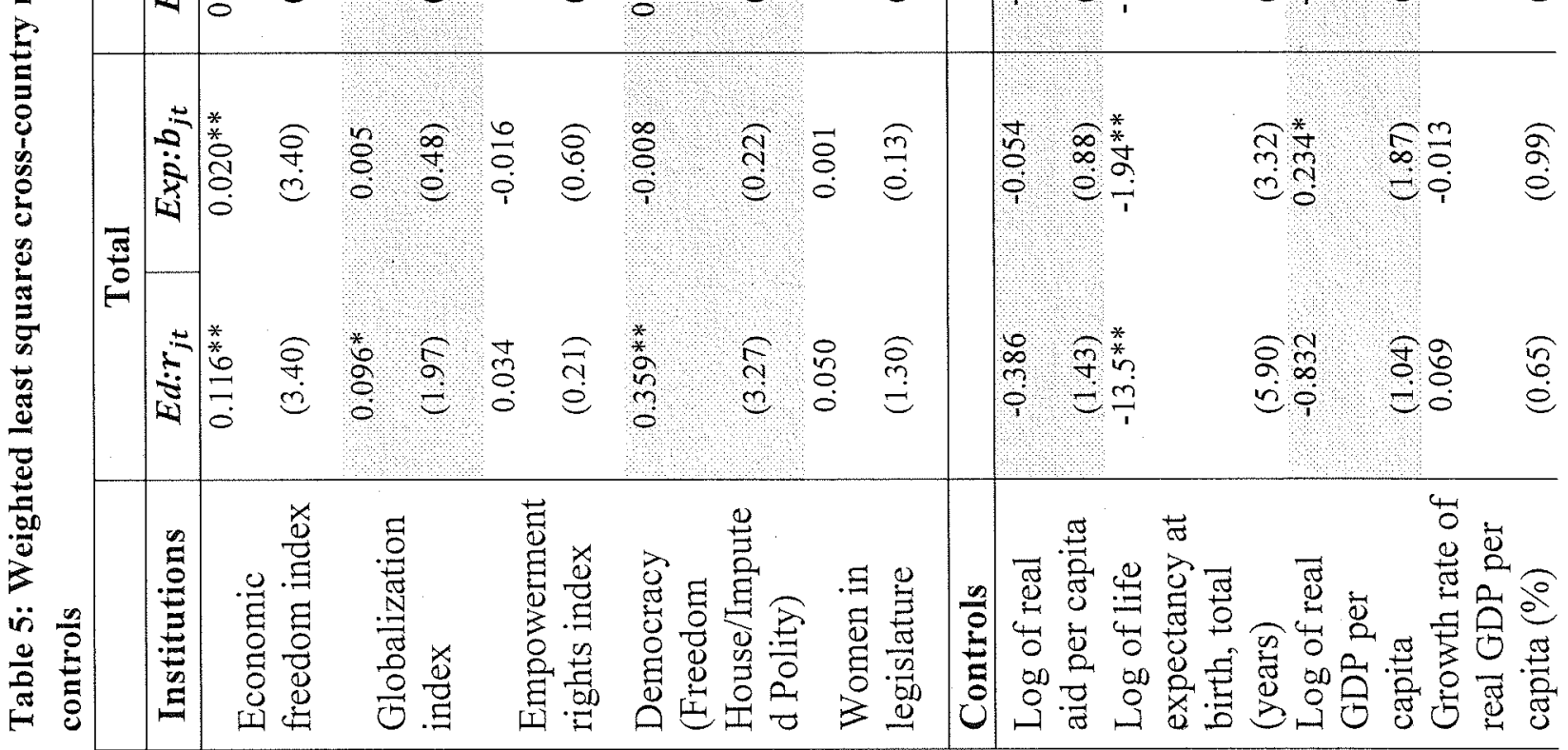




\begin{tabular}{|c|c|c|c|c|}
\hline 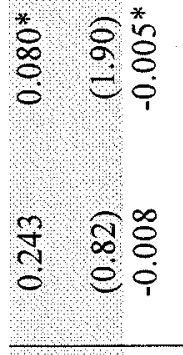 & 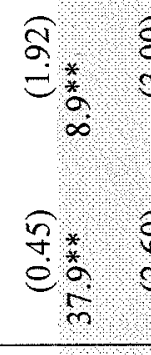 & : & $\begin{array}{l}\cong \\
\cong\end{array}$ & \multirow{2}{*}{ 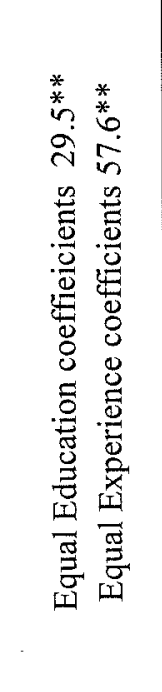 } \\
\hline 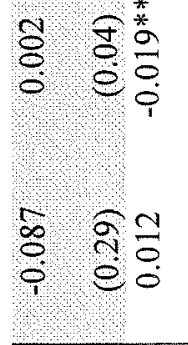 & 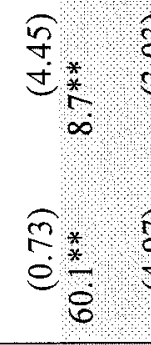 & {$\left[\begin{array}{l}\infty \\
0\end{array}\right.$} & $\begin{array}{l}\Xi \\
\Xi\end{array}$ & \\
\hline 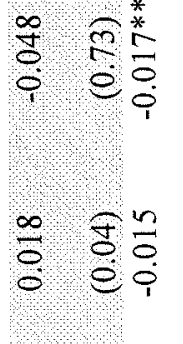 & 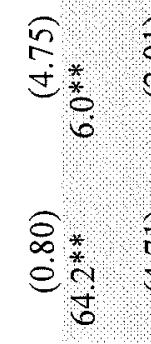 & is & I & \multirow{2}{*}{ 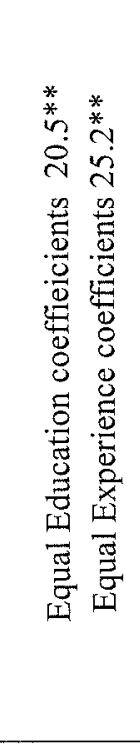 } \\
\hline 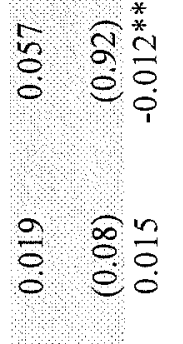 & 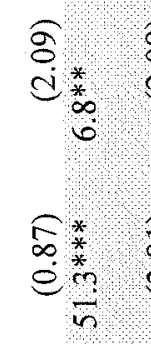 & is & $\Xi$ & \\
\hline 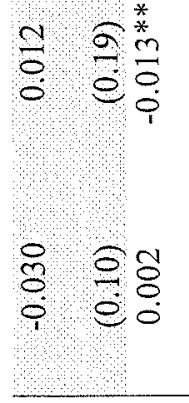 & 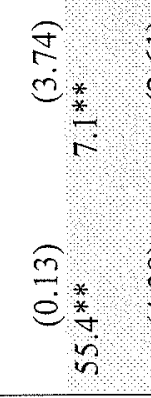 & tiv & $\Xi$ & \\
\hline 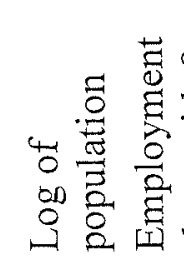 & 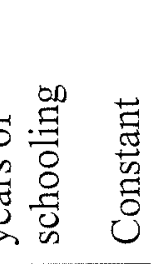 & & 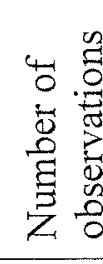 & 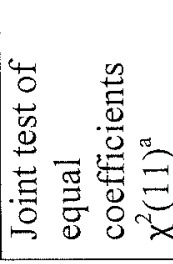 \\
\hline
\end{tabular}




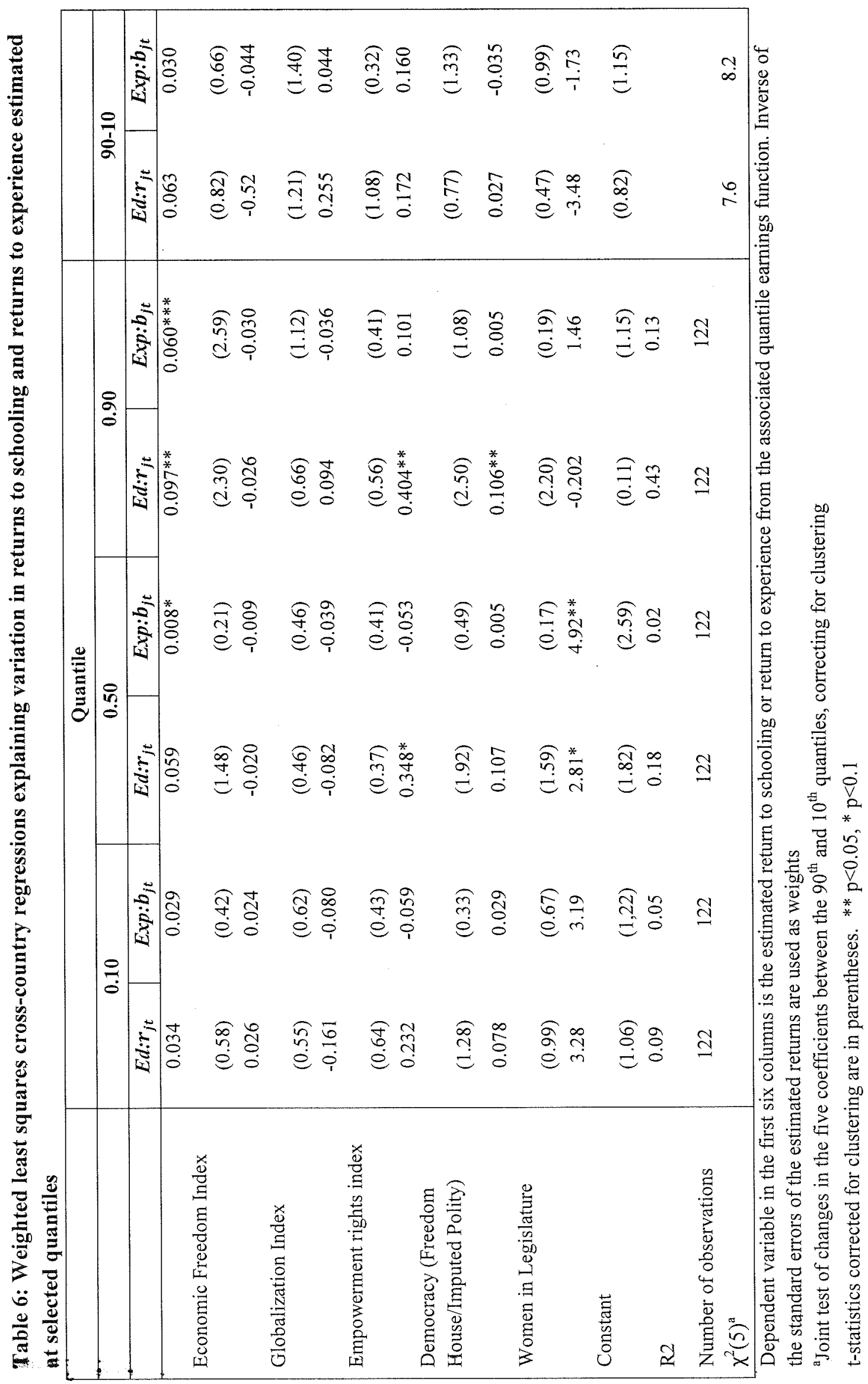




\section{References}

Acemoglu, Daron, and Simon Johnson. 2005. "Unbundling Institutions." Journal of Political Economy 113(5):949-95.

Acemoglu, Daron, Simon Johnson, and James A. Robinson. 2001. "The Colonial Origins of Comparative Development: An Empirical Investigation." American Economic Review 91(5):1369-401.

------. 2005. "The Rise of Europe: Atlantic Trade, Institutional Change, and Economic Growth." American Economic Review 95(3):546-79.

Acemoglu, Daron, Simon Johnson, James A. Robinson, and Yunyong Chaicharoen. 2003. "Institutional Causes, Macroeconomic Symptoms: Volatility, Crises and Growth." Journal of Monetary Economics 50(1):49-123.

Acemoglu, Daron, and James A. Robinson. 2005. Economic Origins of Dictatorship and Democracy. Cambridge: Cambridge University Press.

Alderman, Harold. 2001. "Multi-Tiers Targeting of Social Assistance: The Role of Intergovernmental Transfers." World Bank Economic Review 15(1):33-53.

Autor, David H., Lawrence F. Katz, and Melissa S. Kearney. 2008. "Trends in US Wage Inequality: Revising the Revisionists." Review of Economics and Statistics 90(2):300-23.

Bardhan, Pranab. 2002. "Decentralization of Governance and Development." Journal of Economic Perspectives 16(4):185-206.

-------. 2005. Scarcity, Conflicts and Cooperation: Essays in the Political and Institutional Economics of Development. Cambridge, MA: MIT Press. 
Economic Freedom and Human Capital

Becker, Gary S. 1994. Human Capital: A Theoretical and Empirical Analysis with Special Reference to Education, 3rd. Edition. Cambridge, MA: National Bureau of Economic Research.

Becker, Gary S., and Nigel Tomes. 1979. "An Equilibrium Theory of the Distribution of Income and Intergenerational Mobility." Journal of Political Economy 87(6):1153-89.

-----. 1986. "Human Capital and the Rise and Fall of Families." Journal of Labor Economics 4(3):S1-39.

Black, Sandra E. and Elizabeth Brainerd. 2004. "Discrimination in an Equilibrium Search Model." Journal of Labor Economics 13(2):309-33.

Blau, Francine D., and Lawrence M. Kahn. 2002. At Home and Abroad: US Labor Market Performance in International Perspective. New York, NY: Russell Sage Foundation.

Botero, Juan C., Simeon Djankov, Rafael La Porta Florencio Lopes-de-Silanes, and Andrei Schleifer. 2004. "The Regulation of Labor." Quarterly Journal of Economics 119(4):1339-82.

Card, David. 1999. "The Causal Effect of Education on Earnings." In O. Ashenfelter and David Card, (eds.), Handbook of Labor Economics Vol. 3A. Amsterdam: North-Holland.

Card, David and Alan B. Krueger. 1992. "Does School Quality Matter? Returns to Education and the Characteristics of Public Schools in the United States." Journal of Political Economy 100(1): 1-40.

Caselli, Francesco, and James Feyrer. 2007. "The Marginal Product of Capital." Quarterly Journal of Economics 122(2):535-68. 
Cingranelli, David L., and David L. Richards. 2005. "Measuring the Level, Pattern, and Sequence of Government Respect for Physical Integrity Rights." International Studies Quarterly 43(2):407-17.

Clark, Gregory. 2007. A Farewell to Alms: A Brief Economic History fo the World. Princeton, NJ: Princeton University Press.

Collier, Paul. 2007. The Bottom Billion: Why the Poorest Countries are Failing and What Can be Done about It. Oxford: Oxford University Press.

Djankov, Simeon, Rafael La Porta Florencio Lopes-de-Silanes, and Andrei Schleifer. 2002. "The Regulation of Entry." Quarterly Journal of Economics 117(1):1-37.

Djankov, Simeon, and Peter Murrell. 2002. "Enterprise Restructuring in Transition: A Quantitative Survey." Journal of Economic Literature 40(September):739-92.

Dreher, Axel. 2006. "Does Globalization Affect Growth? Evidence from a New Index of Globalization." Applied Economics. 38(10):1091-110.

Durlauf, Steven N., Paul A. Johnson, and Jonathan R. W. Temple. 2005. "Growth Econometrics." In Philippe Aghion and Steven N. Durlauf, (eds.), Handbook of Economic Growth Vol. 1A. Amsterdam: North Holland.

Easterly, William. 2006. The White Man's Burden: Why the Wet's Efforts to Aid the Rest Have Done so Much Ill and so Little Good. New York, NY: Penguin Press.

------. 2009. "Can the West Save Africa?" Journal of Economic Literature 47(2):373-447.

Faguet, Jean-Paul. 2004. "Does Decentralization Increase Responsiveness to Local Needs? Evidence from Bolivia." Journal of Public Economics 88(3-4):867-94.

Firebaugh, Glenn. 2003. The New Geography of Global Income Inequality. Cambridge, MA: Harvard University Press. 
Fleisher, Belton M., Klara Sabirianova, and Xiaojun Wang. 2005. "Returns to Skills and the Speed of Reforms: Evidence from Central and Eastern Europe, China and Russia." Journal of Comparative Economics 33(2):351-70.

Florida, Richard. 2007. The Flight of the Creative Class: The New Global Competition for Talent. New York, NY: Harper-Collins Publishers.

Frydman, Roman, Cheryl Gray, Marek Hessel, and Andrzej Rapaczynski. 1999. "When Does Privatization Works? The Impact of Private Ownership on Corporate Performance in the Transition Economies." Quarterly Journal of Economics 114(4):1153-91.

Galasso, Emanuela, and Martin Ravallion. 2005. "Decentralized Targeting of an Anti-Poverty Program." Journal of Public Economics 89(4):705-27.

Hanushek, Eric A., and Ludger Woessmann. 2008. "The Role of Cognitive Skills in Economic Development." Journal of Economic Literature 46(3):607-68.

Hanushek, Eric A. and Lei Zhang. 2009. "Quality-Consistent Estimates of International Schooling and Skill Gradients." Journal of Human Capital, 3(2):

Heckman, James J., and Carmen Pages. 2004. Law and Employment: Lessons from Latin America and the Caribbean. Cambridge, MA: National Bureau of Economic Research.

Judge, George G., William E. Griffiths, R. Carter Hill and Tsoung-Chao Lee. 1980. The Theory and Practice of Econometrics. New York, NY: John Wiley and Sons.

Katz, Lawrence F., and David H. Autor. 1999. "Changes in the Wage Structure and Earnings Inequality." In O. Ashenfelter and David Card, (eds.), Handbook of Labor Economics Vol. 3. Amsterdam: North-Holland. 
Kaufmann, Daniel, Aart Kraay, and Massimo Mastruzzi. 2008. "Governance Matters VII: Aggregate and Individual Governance Indicators for 1996-2007." Washington, DC: World Bank Policy Research Working Paper Series 4654.

King, Elizabeth M., Claudio Montenegro and Peter F. Orazem.2012. Appendix to "Economic freedom, human rights, and the returns to human capital: an evaluation of the Schultz hypothesis." http://www2.econ.iastate.edu/faculty/orazem/Appendix_K_O_M_2012.pdf

Lucas Jr., Robert E. 1990. "Why Doesn't Capital Flow from Rich to Poor Countries?" American Economic Review 80(2):92-6.

-------. 2002. Lectures of Economic Growth. Cambridge, MA: Harvard University Press. McMillan, John, and Christopher Woodruff. 2002. "The Central Role of Entrepaneurs in Transition Economies." Journal of Economic Perspectives 16(3):153-70.

Melander, Erik. 2005. "Gender Inequality and Intrastate Armed Conflict." International Studies Quarterly 49(4):695-714.

Milanovic, Branko. 2006. "Global Income Inequality: What it is and Why it Matters?" Washington, DC: World Bank Policy Research Working Paper Series 3865. Mincer, Jacob. 1974. Schooling, Experience, and Earnings. New York, NY: Columbia University Press.

Montenegro, Claudio E., and Harry A. Patrinos. 2009. "Returns to Schooling Around the World." World Bank. Washington, DC. Processed.

Murphy, Kevin M., Andrei Schleifer, and Robert W. Vishny. 1991. "The Allocation of Talent: Implications for Growth." Quarterly Journal of Economics 116(2):503-30.

-----. 1993. "Why is Rent-Seeking So Costly to Growth?" American Economic Review 83(2):409-14. 
Nickell, Stephen, and Richard Layard. 1999. "Labor Market Institutions and Economic Performance." In Orley C. Ashenfelter and David Card, (eds.), Handbook of Labor Economics Vol. 3C. Amsterdam: North Holland.

Nickell, Stephen, Luca Nunziata, and Wolfang Ochel. 2005. "Unemployment in the OECD Since the 1960s. What do we Know?" Economic Journal 115(500):1-27.

Orazem, Peter F., and Elizabeth M. King. 2008. "Schooling in Developing Countries: The Roles of Supply, Demand and Government Policy." In T. Paul Schultz and John Strauss, (eds.), Handbook of Development Economics Vol. 4. Amsterdam: North-Holland.

Orazem, Peter F., and Milan Vodopivec. 2009. "Do Market Pressures Induce Economic Efficiency? The Case of Slovenian Manufacturing, 1994-2001." Southern Economic Journal 76(2):553-76.

Pissarides, Christopher A. 2000. Equilibrium Unemployment Theory, 2nd Ed. Cambridge, MA: MIT Press.

Psacharopoulos, George. 1973. Returns to Education: An International Comparison. San Francisco, CA: Elsevier-Jossey Bass.

------. 1994. "Returns to Investmen in Education: A Global Update." World Development 22(9):1325-43.

Psacharopoulos, George, and Harry A. Patrinos. 2004. "Returns to Investment in Education: A Further Update." Education Economics 12(2):111-34.

Romer, Paul M. 1986. "Increasing Returns and Long-Run Growth." Journal of Political Economy 94(5):1002-37.

-----. 1990. "Endogenous Technical Change." Journal of Political Economy 98(5-2):S71-102. 
Rosen, Sherwin. 1983. "Specialization and Human Capital." Journal of Labor Economics $1(1): 43-9$.

Sachs, Jeffrey. 2005. The End of Poverty: Economic Possibilities for our Time. New York, NY: Penguin Press.

Schleifer, Andrei, and Robert W. Vishny. 1993. "Corruption." Quarterly Journal of Economics 108(3):599-617.

Schultz, T. Paul. 1988. "Education Investment and Returns." In Hollis Chenery and T. N. Srinivasan, (eds.), Handbook of Development Economics Vol. 1. Amsterdam: NorthHolland.

-------. 1998. "Inequality in the Distribution of Personal Income in the World: How It is Changing and Why." Journal of Population Economics 11(3):307-44.

-------. 1999. "Health and Schooling Investments in Africa." Journal of Economic Perspectives 13(3):67-88.

Schultz, Theodore W. 1975. "The Value of Ability to Deal with Disequilibria." Journal of Economic Literature 13(3):827-46.

World Bank. 2009. World Development Report 2007: Development and the Next Generation Washington D.C.: The World Bank.

Xu, Bin. 2000. "Multinational Enterprises, Technology Diffusion, and Host Country Productivity Growth." Journal of Development Economics 62(2):477-93.

Yang, Xiaokai. 2003. Economic Development and the Division of Labor. Malden, MA: Blackwell Publishers. 
Endnotes

${ }^{1}$ This is despite also well-known differences in the quality of schooling across countries and across levels of schooling in those countries, a point that Hanushek and Zhang (2009) and Hanushek and Woessmann (2008) make. In addition, what is interpreted as returns to acquired human capital may reflect also returns to innate ability for which there are no common measures.

${ }^{2}$ See Table 4 in Card (1999) for a summary of recent estimated returns to schooling in developed countries. Recent reviews of returns to schooling in developing countries include Orazem and King (2008) and Montenegro and Patrinos (2009).

${ }^{3}$ In our investigation of 122 developing country data sets, only 2 failed to generate positive returns to schooling and 7 failed to generate rising returns to age.

${ }^{4}$ Information on the Heritage Foundation Index is available at http://www.heritage.org/research/features/index/chapters/pdfs/Index2006 Chap5.pdf

${ }^{5}$ We use private returns to schooling as those are the ones that motivate individual time allocation choices. Countries may dictate individual educational choices and time allocations in ways to maximize social returns to schooling, but that would not correspond to T.W. Schultz's focus on the returns to individual choice.

${ }^{6}$ Similar findings that $60-70 \%$ of world income inequality is due to income inequality between rather than within countries results are reported in reviews by Firebaugh (2003) and Milanovic (2006). Firebaugh (2003), p. 92) argues that between-country inequality has fallen recently, but that the between-nation component of global inequality is still "as much as three times the size of the within-nation component."

${ }^{7}$ See Acemoglu, Johnson, and Robinson (2005), p. 316.

${ }^{8}$ Orazem and Vodopivec (2009) used the Schultz hypothesis to explain rising returns to schooling in Slovenia and for transition economies more generally.

${ }^{9}$ The transition economy experience cannot tell us which institutions are important for returns to human capital because many of these institutions such as rule of law, protection of property rights, wage flexibility, monetary reforms, exposure to international trade, were changing simultaneously.

${ }^{10}$ Botero and others (2004) and Djankov, Lopes-de-Silanes, and Schleifer (2002) are prominent examples of this strategy.

${ }^{11}$ For examples see the various papers by Acemoglu, Johnson, and Robinson (2001).

${ }^{12}$ Examples include Blau and Kahn (2002), Heckman and Pages (2004), and Nickell, Nunziata, and Ochel (2005). 
${ }^{13}$ Additional details about the measures are discussed in King, Montenegro and Orazem (2012.

${ }^{14}$ We used the Heritage Foundation indices that matched most closely the date of each country household survey. For five countries which were not covered in the Heritage Foundation Index, we use the fitted values from regressions of the index on the six measures included in the World Bank's Governance Indicators (Kaufmann, Kraay, and Mastruzzi 2008).

${ }^{15}$ We use the data for the year that matches most closely the date of the country household survey.

${ }^{16}$ Nevertheless, there are exceptions. Democratic countries that offer above-average levels of individual rights but below-average protection of those rights include Indonesia, Kenya, Turkey, Sierra Leone, Gambia, and Haiti. Bahrain and the United Arab Emirates score low on democracy and individual rights, but offer high levels of economic freedom. The Ukraine offers high levels of democracy and individual rights, but below-average economic freedoms.

${ }^{17}$ We have repeated observations for some countries at different points in time. Four data sets are from Chile, three each from Bulgaria, El Salvador, Guatemala and Uruguay; and two data sets from 25 other countries.

${ }^{18}$ See Becker and Tomes $(1979,1986)$ for the theoretical proof of this proposition. A large literature has demonstrated that income shocks atypically cause poor households to reduce schooling investments while wealthier households absorb shocks, consistent with the presence of liquidity constraints (Orazem and King, 2008, pp.3521-3534.

${ }^{19}$ We can only include individuals in the regression if they work for a wage. That means that our estimated returns are potentially subject to selection on labor supply. To investigate the importance of selection, we also estimated the returns using a Heckman selection correction which used aggregate household income and the presence of children as instruments in the probit selection equation. As shown in King, Orazem and Montenegro (2012), OLS and selectioncorrected returns are highly correlated, consistent with the findings in Schultz (1999). We use the OLS estimates because only 90 data sets incorporated sufficient information to identify the selection equation, meaning a sacrifice of $26 \%$ of the sample if we limited the results to the selection corrected set.

${ }^{20}$ See Judge et al (1980), pp. 125-128. Note that the Stata weighted least squares program with analytical weights requires that we specify the weight as the inverse of the variance rather than the standard error. A similar estimation strategy was employed by Card and Krueger (1992) in their evaluation of the role of school quality on returns to schooling in the United States.

21 The unit of observation is the market and not the individual, and so it is not appropriate to weight these regressions by population. Nevertheless, we did perform a population-weighted regression to examine how sensitive our results were to alternative specifications. Because 
India, Indonesia and Pakistan had such dominant population size compared to the rest of the countries, standard weighting methods forced the coefficients to 'explain' those few large countries, effectively negating the variation across economic institutions in the data. When we use an alternative of eliminating the relatively few very large countries form the data set, we get results comparable to those reported in the paper.

${ }^{22}$ When exact matches on years were not available, we interpolated between years.

${ }^{23}$ We experimented also with using average years of schooling. Results are similar; years of schooling are negatively correlated with average returns to schooling, consistent with the hypothesis of diminishing returns. However, years of schooling responds to other factors besides life expectancy including expectations of returns to schooling, and so life expectancy can more plausibly be viewed as a factor shifting outward the country's demand for schooling rather than a response to returns to schooling.

${ }^{24}$ Several colleagues asked whether our results are driven by variation in school quality across countries, perhaps because countries that score highly in economic freedom, women's political representation and democracy are also the countries with the best schools. School quality has been argued to explain variation in economic growth across countries (Hanushek and Woessmann 2008). We replicated the regressions in Table 1 with measures of expenditures per pupil for the subset of countries for which information was available. None of our conclusions are sensitive to inclusion of that measure of school quality. 
Figure 1: Histograms of estimated returns to schooling and to work experience across developing countries
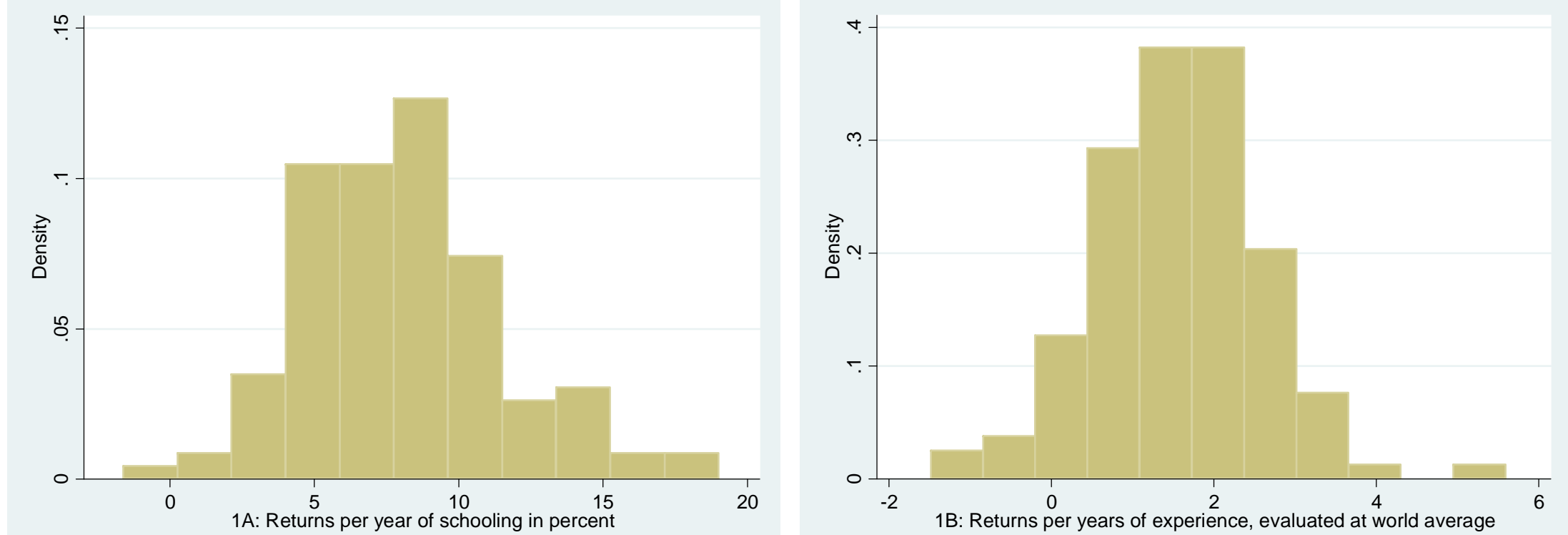

Source: Authors' calculations based on the coefficients from earnings function regressions applied to 122 household survey data sets covering 86 countries 
Figure 2: Returns to schooling by level of development and economic freedom

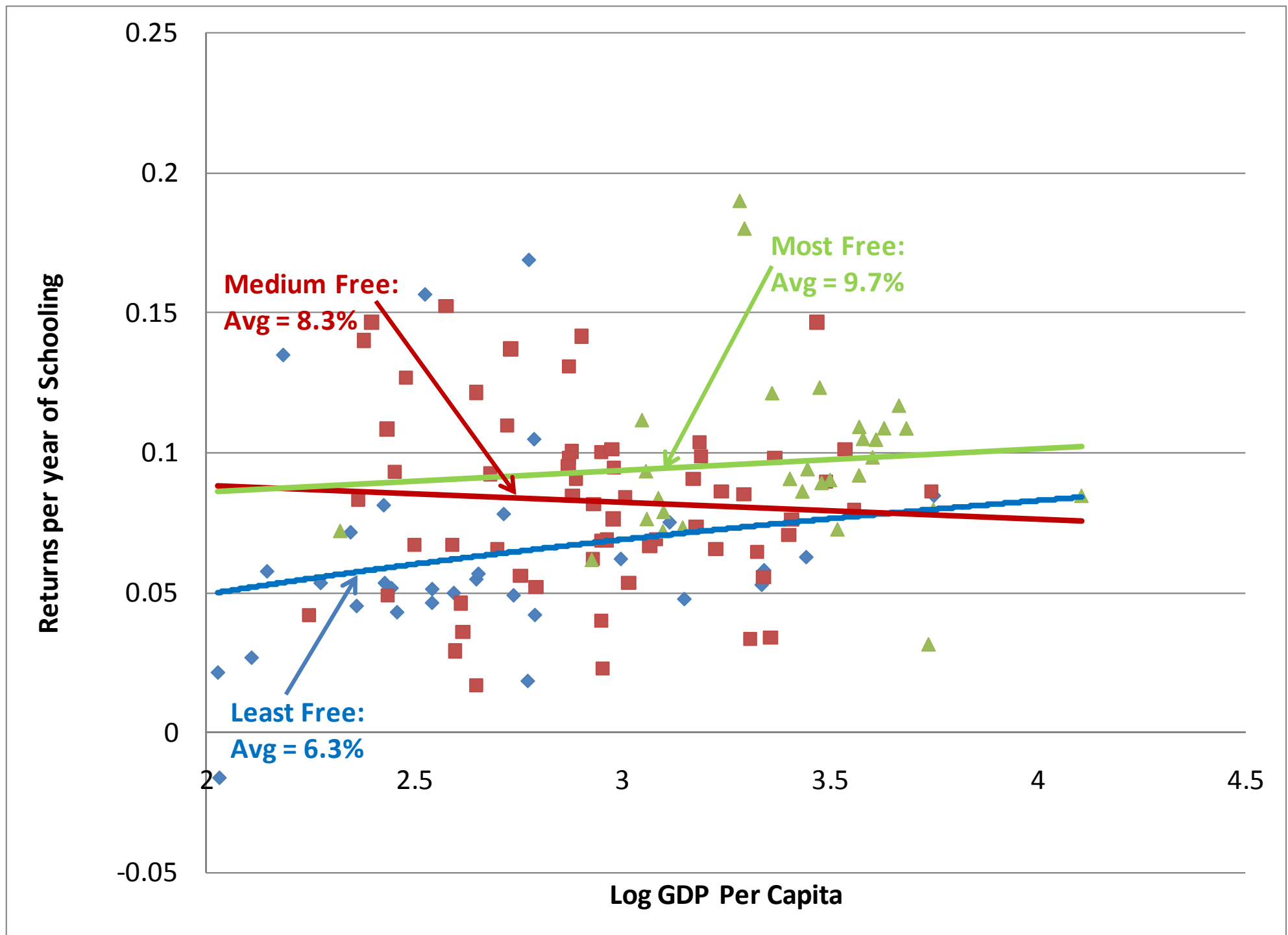


Figure 3: Returns to experience by level of development and economic freedom

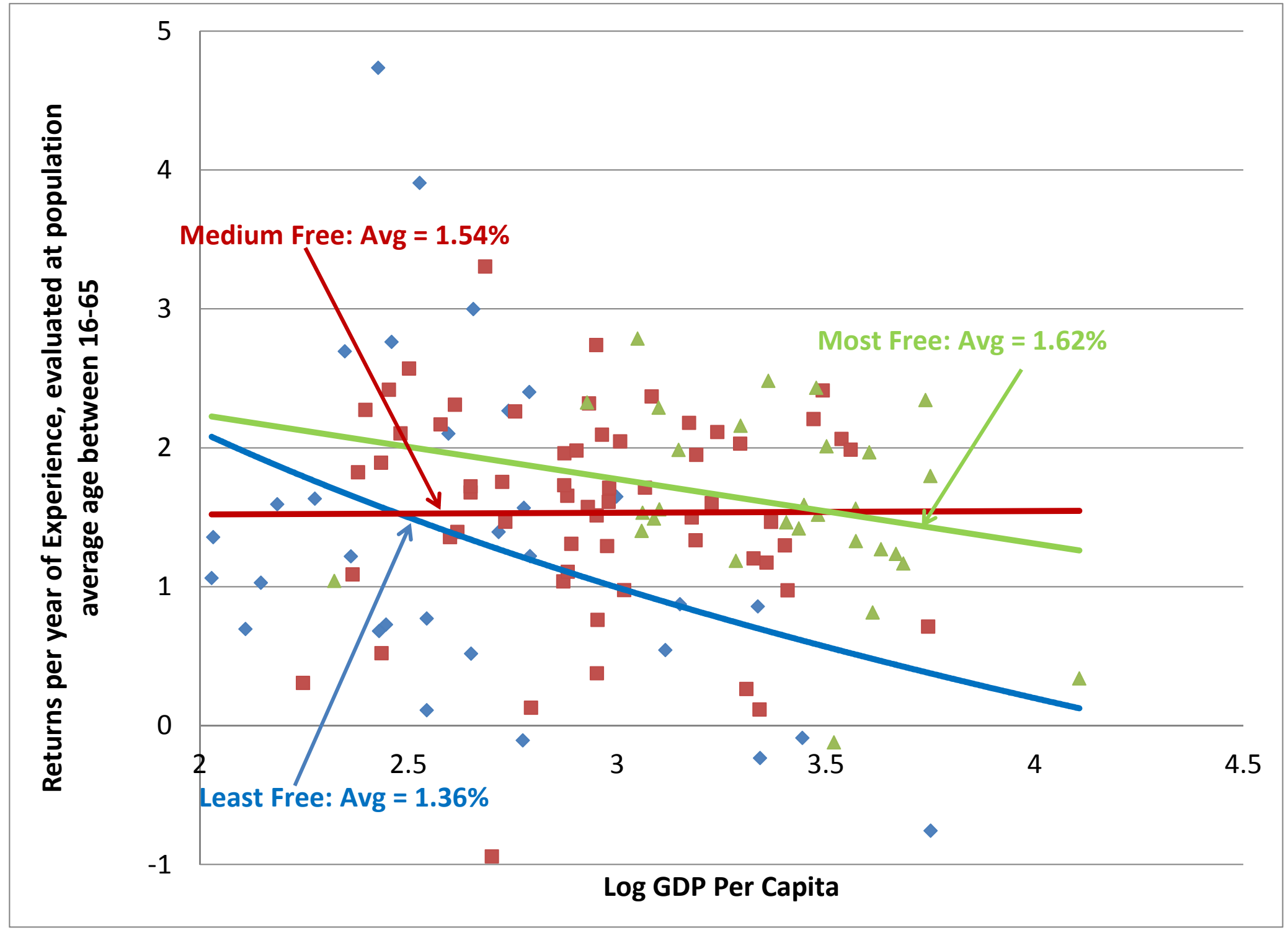

